\title{
Brief Discussion of the Former Performance Appraisal System of Civil Servant under the Law Number \\ 87/89/M in Macau
}

\author{
I Man Chiang \\ Direcção dos Serviços de Protecção Ambiental \\ E-mail: helloamanda104@gmail.com \\ Luis Miguel Dos Santos (Corresponding author) \\ Customs Training Center \\ Macau Customs Service, Macau, Macau China \\ E-mail: luismigueldossantos@yahoo.com
}

Received: June 12, 2017 Accepted: June 28, 2017 Online published: July 10, 2017

doi:10.5296/jpag.v7i3.11383 URL: https://doi.org/10.5296/jpag.v7i3.11383

\begin{abstract}
The Macau Special Administrative Region has experienced a large number of changes before and after the Transfer of Sovereignty over Macau from the Portuguese Republic to the People's Republic of China during the late 1999s. One of the most significant changes within the government environment should be the reform of civil servant appraisal system. Currently, the civil servants in Macau are using the new civil servant appraisal system framework under the Law Number 31/2004 "Regime geral de avaliação do desempenho dos trabalhadores da Administração Pública". As the new appraisal system attracts a large number of attentions for research, a satisfied number of literature reviews are stored in the current research bank. However, the literature reviews and research studies about the former civil servant appraisal system framework under the Law Number 87/89/M "Estatuto dos Trabalhadores da Administração Pública de Macau" were mostly written in either Chinese language or Portuguese language. Only very few English written research studies concern the former civil servant appraisal system under the Law Number 87/89/M "Estatuto dos Trabalhadores da Administração Pública de Macau". Therefore, this paper provides the opportunities for international and English readers to understand the administrative law reform within the Macau environment.
\end{abstract}


Keywords: Administrative policy, civil servant appraisal system, policy reform, political science, Macau

\section{Introduction and Purpose of This Paper}

Before the Transfer of Sovereignty over Macau from the Portuguese Republic to the People's Republic of China during the late 1999s, Macau was occupied by the Portuguese government for more than 400 years. During the late 1900s, the Macau-Portuguese government has established a set of Civil Servant Appraisal System under Law Number 87/89/M "Estatuto dos Trabalhadores da Administração Pública de Macau" for the purpose of performance appraisal. However, after the Transfer of Sovereignty during the late 1999s, the social and economic environments have been changed rapidly in Macau. Besides the governmental changes, the population demographic, the population of civil servants, and educational difficulties etc. also experienced numbers of changes. As the former civil servant appraisal system was established during 1980s, such system may not able to respond to the essential needs of the current environment and society. As result, a new Civil Servant Appraisal System under Law Number 31/2004 "Regime geral de avaliação do desempenho dos trabalhadores da Administração Pública" was established in order to responds to the current society.

The purpose of this paper is to discuss and establish a brief outline of the former Civil Servant Appraisal System under Law Number 87/89/M "Estatuto dos Trabalhadores da Administração Pública de Macau”. This paper is divided into 4 major contents, including Chapter 2 the literature review, Chapter 3 the Former Civil Servant Appraisal System under Law Number 87/89/M "Estatuto dos Trabalhadores da Administração Pública de Macau", Chapter 4 the Special Appraisal System of the Former Civil Servant Appraisal System under Law Number 87/89/M "Estatuto dos Trabalhadores da Administração Pública de Macau”, and Chapter 5 the Shortcomings of the Former Civil Servant Appraisal System under Law Number 87/89/M "Estatuto dos Trabalhadores da Administração Pública de Macau". The paper aims to provide a historical perspective from this former Civil Servant Appraisal System under Law Number 87/89/M "Estatuto dos Trabalhadores da Administração Pública de Macau" to readers who intend to understand the reforms and developments of administrative and governmental laws in Macau.

\section{Literature Review of Appraisal System}

In Jonathan Tompkins's book, Human Resource Management in Government (1995), "performance appraisal is the process of communicating work expectation, evaluating employee performance, and encouraging performance improvements." (Tompkins, 1995, 243-244). In fact, performance appraisal can provide a wide range of benefits as long as done with care. For instance, its results can be used to determine training needs, identify candidates for promotion, and allocate rewards such as merit pay; simultaneously the feedback given to employees can also improve motivation and productivity (Tompkins, 1995). As a result, performance appraisal is one important aspect of personnel management as it can provide basis for rewards, promotion, training and merit pay to the employees. 
Lacking a scientific and objective performance appraisal system will lead to the loss of basis towards personnel management, if performance appraisal is not done with care, which means the supervisors cannot exactly understand and master the overall situation of the employees that are under performance assessment, thus objective and fair assessment results cannot be obtained (Waldo, 2006). Based on the research question - exploring whether the new performance appraisal system can motivate the staff, the definition of motivation must be clearly defined. Motivation is the processes that account for an individual's intensity, direction, and persistence of effort toward attaining a goal. Besides, general motivation refers to efforts toward any goal. Three specific theories were formulated during the 1950 s which were a fruitful development period of motivation concepts; they are hierarchy of needs theory, Theories X and Y, and the two-factor theory. These three theories are significant as they represent a foundation from which contemporary theories have grown; more importantly practicing managers still regularly use these theories and their terminology in explaining employee motivation (Heady, 2001).

\subsection{Significance of Performance Appraisal}

One of the intent of performance appraisal is it provides chances of self-evaluation and promotion to the employees. For instance, some workers who always perform well and they might want to get the recognition of the supervisors, get the rewards they desire or even achieve their self-realization; the performance appraisal can provide these chances to them.

For the employees whose performances are not so well or even bad, performance appraisal can help them more understand their working situation and provide them with some useful suggestion to them so as to help them to improve their working performance. Besides, performance appraisal make managers at all levels clearly understand the working situation of their subordinates, and this is good for enhance the efficiency of management, for example, distribution and assignation of workers can be carried out more properly. In addition, it provides communication channel to the supervisors and subordinates, and this strengthen communication between the upper and the lower levels, thus mutual trust can be established between them; Last but not least, performance appraisal contributes to the attainment of organizational goals. Through performance appraisal to know how much the employees had contributed to the goals of the organization; also conduct some relevant analysis and combine internal and external factors to the achievement of organization objective, thereby helping to attain the goals that the organization wants (Waldo, 2006).

In summary, the researchers understood that performance appraisal is a mean but not an end in personnel management. Its intention is to help employees understand their potential as well as to help them play their potential, thereby improving their working situation, enhancing their working efficiency and eventually help to attain the organizational goals.

\subsection{Principles of Performance Appraisal}

According to Zhang (2002), performance appraisal should be conducted based on the following principles:

First, for equity and certainty perspective, performance appraisal cannot use fragment and 
temporary information, also should not be affected by subjective factors, thus performance appraisal should be handled with objective and impartial manner.

Second, for attention to virtue and people who have ability, the assessment items should include both internal and external characters, those who only have good virtue but poor in performance will not be the best employees, and vice versa. Therefore attention should be put in both virtue and personal ability.

Third, for objectivity and carefulness, performance appraisal should be in accord with the content of various functions, respectively apply different performance standards, the reason are different positions will have different natures, thus requirement of performance criteria and standards will be different accordingly.

Fourth, for conscientiousness and strictness, given certain rewards to the employees whose performance is good, while given certain penalties to those who perform bad, thereby each employee can truly have consciousness that performance appraisal system has the role of assessment and trust that system, thus it can provide positive motivation to the employees while simultaneously it can provide deterrent effect on the negative side to the employees also.

In sum, I totally agree with those principles that supervisors should appraise the civil servants in accord with them, but I think integrity and law-abiding is also very important to civil servants; the directors must rate their subordinates according to integrity and law in order to maintain or enhance the legitimacy of the government.

\subsection{Functions of Performance Appraisal}

According to Zhang (2002), functions of performance appraisal can be divided into five categories:

First, performance appraisal can improve the personnel system. Rewards and punishments could be given to the civil servants through the results of performance assessment, rewarding those perform well while punishing that performance is bad based on the performance indicators provided by the performance appraisal, thereby facilitating motivation to the employees and make the personnel system become more perfect.

Second, performance appraisal help finding those who have ability put them in correct use. The assessment system made the supervisors understand more about the characters, abilities as well as advantages of different employees. This will be an important reference on the use of personnel in the government.

Third, performance appraisal can strengthen the leadership of directors and enhance the relationship between the upper and the lower levels. Performance appraisal give the autonomy to the directors to appraise subordinates, having more autonomy strengthen the leadership, also through the interactions during the process of performance appraisal, they can understand each other more.

Fourth, performance appraisal provides basis of motivation. In fact, performance appraisal is 
a means but not an end, in order to truly reflect the role and function of assessment; it must link to a variety of incentives.

To conclude, one of the core questions for government management is to enhance performance of civil servants, in order to improve the performance means the requirement of understanding the current performance level firstly. Knowing the functions of performance appraisal is meaningful to improve and enhance the performance of government.

\subsection{Factors Affecting the Performance Appraisal from Individual Perspectives}

According to Tompkins (1995), performance appraisals rarely deliver in practice what they promise in theory and this is a paradox well worth exploring. Gu (2006) outlined 4 dimensions for individual factors, which are: 1) attention and support by the managers; 2) understanding and support by the staff; 3) the problems of evaluators; and 4) the problems of those being evaluated.

\subsubsection{Attention and Support by the Managers}

This is the key factor in determining whether a performance appraisal system can be successful. Supervisors perceive that is a meaningless and troublesome work, considering it as a burden, but the others see it as important management activities.

\subsubsection{Understanding and Support by the Staff}

Supervisors should always tell and communicate to the employees about the purpose and significance of performance appraisal and explain the reliability of the assessment methods, thereby gaining the recognition, understanding and support by the subordinates.

\subsubsection{The Problems of Evaluators}

Even design of the performance appraisal system is appropriate but if there were no appropriate match with the evaluators, the system cannot function properly.

First, contrast effects could occur. This refers to the tendency to rate employees relative to each other rather than to actual job requirements. For instance, a good performer may be given an average-level rating for no other reason than that he or she did not perform quite as well as someone else. However, in these instances, a rating such as average-level should be determined in relation to how well an individual has met the performance standards (Tompkins, 1995).

Second, first impression error. This concept refers to the tendency to rate individuals based on first impressions and then to ignore or discount information that does not support those first impressions. For example, an employee who performs very well when first hired, may continue to receive good ratings even after his or her performance has regressed (Tompkins, 1995).

Third, halo effect. This refers to the tendency to rate an individual consistently high or low across all performance dimensions based on only one aspect of job performance. For instance, a supervisor who is impressed with an individual's interpersonal skills may generalize this 


\section{Mll Macrothink}

Journal of Public Administration and Governance

ISSN 2161-7104

2017, Vol. 7, No. 3

favorable impression to other areas of the individual's work performance whether or not such generalizations are warranted (Tompkins, 1995).

Fourth, similar-to-me effect. This refers to the tendency to judge persons more favorably who are perceived to be similar to one's self. The troubling implication of this is that raters may evaluate the same work behaviors differently depending on their own race, gender, educational background or organizational roles. For example, a supervisor may give a good result to an employee who is similar to himself or herself (Tompkins, 1995).

Fifth, central tendency error. This refers to the tendency to rate all individuals close to the midpoint of a scale regardless of their actual levels of performance. It occurs because raters are unable or unwilling to carefully differentiate between distinct levels of performance. Some supervisors, for example, give only average ratings because they believe there is always room for improvement, and others simply play it safe by refusing to label individuals as either superior or poor performers (Tompkins, 1995).

Sixth, constant error. There are managers who evaluate their employees according to standards that are above or below the norm. These evaluations are often adjusted by others, in that they treat the employee as having been judged too harshly or too generously because of who evaluated them (Tompkins, 1995).

Seventh, regency error. When evaluations are completed once a year, the evaluators tend to remember the most recent performance and not weigh equally the pattern of performance throughout the year (Tompkins, 1995).

Eighth, personal bias. Stereotypes and prejudices abound in our society and make their way into individual judgments about other people. If supervisors believe there is substance behind ethnic images, fear the consequences of disabilities that they do not fully understand, or hold to traditional distinctions between the sexes, then evaluations are likely to reflect those views and fears (Tompkins, 1995).

\subsubsection{The Problems of Those Being Evaluated}

Some employees do not want to be appraised; particularly those who want to maintain the status quo or those do not seek improvement. Besides, some employees whose self-evaluation is too high while others are too modest, all this will bring negative effect and results $(\mathrm{Gu}$, 2006).

\subsection{Factors Affecting the Performance Appraisal from Organizational Perspectives}

Besides individual and personal factors, organizational elements could influence the appraisal system and outcome as well. Gu (2006) outlined 4 dimensions for organizational factors, which are: 1) the characteristics within the organization; 2) appraisal criteria and methods; 3) the feedback mechanism of performance appraisal; and 4) the reliability and validity of performance appraisal.

\subsubsection{The Characteristics within the Organization}

The degree of communication and features of culture within the organization will promote or 
hinder the implementation of performance appraisal and affect the process of appraisal. For instance, in a closed, trust-lacked organization, good performance is difficult to achieve.

\subsubsection{Appraisal Criteria and Methods}

Choosing adequate appraisal criteria and methods help ensure technical support for successful performance appraisal. Only when the criteria and methods are adequate, thereby the result will be convincing and functions of assessment can be obtained.

\subsubsection{The Feedback Mechanism of Performance Appraisal}

Without feedback mechanism leads those employees being evaluated cannot have channel to defend themselves, also do not have chance to know the degree of fit between their self-performance and expectation of their organization, therefore this performance appraisal system will lose its important role in improving staff performance.

\subsubsection{The Reliability and Validity of Performance Appraisal}

The former assessment criteria for the same position at different times should remain the same. Meanwhile, the assessment criteria for the employees who are in the same position but evaluated by different evaluators should also have to be consistent. Nevertheless, validity of performance appraisal means appraisal criteria needs to be correct, reasonable and legal, assessment items need to be linked with job requirements, the weight of the scoring of assessment between different assessment items should be reasonable, that means the weight should be adapted according to importance of main duties, inferior duties and related responsibilities on different positions.

Actually, those factors affecting the performance appraisal include three main categories: individual, organizational and social factors, but the last factors do not fall into the scope of discussion about this research, thus relevant content may not be introduced. In sum, in order to deliver what performance appraisal promise in theory into practice, organizations should pay attention to these factors; otherwise, they will be serious obstacles for attaining the satisfied results.

\subsection{Main Purposes of the Performance Appraisal}

After a whole discussion of appraisal system, Tompkins (1995) concluded the major purpose of performance appraisal system for both individual and organizational levels.

\subsubsection{Directing and Controlling Behavior}

In the appraisal systems, the measurement criteria and performance standards direct the attention of employees to what is to be done and how. Because job retention, promotions, and merit pay often depend on performance ratings, also appraisals can also one method to control employees, such as the implicit threat of withholding desired rewards can help ensure that employees are submissive to authority.

\subsubsection{Validating Administrative Decisions}

According to Tompkins (1995), the most frequently cited reason for maintaining appraisal 
systems are to provide the data needed to make administrative decisions. In order to achieve this purpose, supervisors are asked to compare employees with each other, either directly or directly and to assign an overall performance score or ranking to each. And the scores or rankings are then used to determine which employees are most deserving of promotion, transfer, financial bonuses or discipline, therefore appraisal systems can help to make and validate administrative decisions.

\subsubsection{Improving Work Performance}

This purpose is accomplished by clarifying work expectations, identifying work deficiencies and determining how to improve future performance through the performance appraisals and its process. For instance, it may be determined that some of the employees inside the Macau government need additional training and others lack the necessary motivation.

\subsubsection{Developing Employee Capabilities}

Appropriate appraisal systems could encourage employees to perform in accord with the organizational goals, as well as to arrange relevant training and professional development beyond that which is needed to perform current job duties to the employees.

In conclusion, it is unrealistic and probably undesirable to expect a single performance appraisal instrument to accomplish all four purposes at once as he mentioned. The reasons are the purposes described are partially incompatible, and most organizations do not attempt to achieve these purposes in equal measure, some purposes are more important to them than others, thus design and uses of the appraisal systems vary according to which of these purposes they are intended to serve.

\section{The Former Civil Servant Appraisal System under Law Number 87/89/M "Estatuto dos Trabalhadores da Administração Pública de Macau"}

The efficiency and quality of service of civil servants of Macau have been criticized by the general public members before the Transfer of Sovereignty over Macau from the Portuguese Republic to the People's Republic of China during the late 1999s. The underlying cause of this discussion was the lack of a fair and objective appraisal system (Lu, 2004). Due to the absence of fairness and bias for particular groups of civil servants, a large number of complaints and negative voices occurred toward the civil servant industry.

In fact, the public members and research scholars may understand that there is no the best appraisal system, only the most suitable appraisal system (Macau Development Strategy Research Center, 2003). The former civil servant appraisal system divided the performance level into excellent, satisfactory, fair, and poor. Based on the assessment results, rewards and punishment will be given. The former civil servant appraisal system in Macau provided 4-score-scale levels, as the following: 
Table 1. Former 4-score-scale appraisal system under Law Number 87/89/M "Estatuto dos Trabalhadores da Administração Pública de Macau"

\begin{tabular}{|l|l|}
\hline \multicolumn{1}{|c|}{ Level } & \multicolumn{1}{c|}{ Score } \\
\hline Excellent & 4 \\
\hline Satisfactory & 3 \\
\hline Fair & 2 \\
\hline Poor & 1 \\
\hline
\end{tabular}

Before the announcement of Law Number 12/2015 "Regime do Contrato de Trabalho nos Serviços Públicos", the human resource manpower of the Macau government had been divided into two major categories, which was civil servant and contract personnel, as the following:

Table 2. Manpower of Macau government before the announcement of the Law Number 12/2015 "Regime do Contrato de Trabalho nos Serviços Públicos"

\begin{tabular}{|l|l|}
\hline \multicolumn{2}{|c|}{ Macau Government Manpower } \\
\hline Category & \multicolumn{1}{c|}{ Characteristics } \\
\hline & $\begin{array}{l}\text { 1) } \begin{array}{l}\text { Do not need to continue to the contact } \\
\text { after 2-year long probation if the servant } \\
\text { received no less than satisfactory for } \\
\text { 2-year. }\end{array} \\
\text { Contact Personnel }\end{array}$ \\
$\begin{array}{ll}\text { After the probation, unless the servant } \\
\text { conducted crimes, the government cannot } \\
\text { terminate the position. }\end{array}$ \\
\hline 1) $\begin{array}{l}\text { The contact is 1-year or 2-year long only. } \\
\text { The government can terminate the contact } \\
\text { without any reasons. }\end{array}$ \\
\hline
\end{tabular}

For example, a civil servant was rated as excellent-level or satisfactory-level for two consecutive years, this person was entitled to an upgrade within pay-scale framework vice-versa for contract personnel. In addition, for the two-year long probation for civil servant, excellent-level or satisfactory-level are also essential. However, if contract-staff received either fair-level or poor-level, the renewability of their contacts will not be provided. On the other hand, if civil servants received a fair-level, the position could not be terminated. Even if the civil servant received a poor-level, only a disciplinary action could occur (Chou, 2004).

However, the overall results of performance assessment in 1999 show that 9269 staff (not including the militarization staff) inside the 37 bureau-level departments, with 5746 people got the assessment results as excellent-level, representing about $62 \%$; followed by 
satisfactory-level, there are 3496 people, representing about $37.7 \%$; only 27 were rated as fair-level, or about 0.3 percent, and there is no one was named poor-level (Lou, 2000). In principle, the civil servants that are highlighted as excellent-level should only be those who had achieved outstanding performance (Lam, 2005). However, based on the results above, more than half of the civil servants were rated as the highest level, the excellent-level. Moreover, there was over 90 percent of civil servants were rated either as excellent-level or satisfactory-level. Since most of the assessment results of the staff were either excellent-level or satisfactory-level, and this caused the public doubted and aroused a great response on taking relevant reform measures to deal with this problem (Lam, 2005). The lost function of the former civil servant appraisal system was commonplace, the government had also recognized the standards of this system are not unified and which is needed to reform (Macau Development Strategy Center, 2003).

The former Secretariat for Administration and Justice Florinda da Rosa Silva Chan (1999-2014) also acknowledged that almost all civil servants received satisfactory-level or excellent-level rating, not just the general public doubted, even if her receipt of the statistics also did not feel normal. She expressed that such a situation occurred, one important issue was the director and relevant personnel with a subjective approach when assessed, such as a civil servant was rated excellent-level in the first year, each year will be same rated as excellent-level because of inertia. Besides, the another problem was the former directors rated their staff as excellent-level every year, and when the new directors took over the duties of the former directors, those new directors did not want to change the assessment results rated by the former directors. Even if the performance of their staff was unsatisfied, they could still inertia be rated excellent-level (The Civil Servant Team Will Select the Excellent but Ignore the Poor, 2000).

Some public members have criticized the problem that supervisors may assess according to his or her personal preference and orientation, or he or she did not want to get into the trouble of appeal by their subordinates. Thus, almost everyone may able to receive the excellent-level result. Moreover, those subordinates under the former assessment framework might therefore try to please the boss, and eventually led to the phenomenon of apple-polishing culture (Face the reform of civil servant appraisal system, 2000).

All of the above showed that the former performance appraisal system had some shortcomings and was imperfect, as most of the staff was either rated as excellent-level or satisfactory-level. Actually, the general public members have been having certain expectations and requirements on the civil servants. Therefore, after the publication of the overall results of performance assessment in 1999, there was increased demand by all sectors of society for taking reform measures to solve this problem (Lam, 2005). As requirements of the general public members increase, so does demand for taking political reform to combat the shortcomings of the former civil servants' appraisal system. Thus, in order to respond to the demands of civil society, the new or current appraisal system named Macau Civil Servant Performance Assessment System entered into operation on January 1, 2005, for assessing the duty performance of Macau public servants (Yin, 2008). All of these problems showed the former system became a ritual and loss of function to distinguish personnel quality and 
working performance of civil servants.

\section{The Special Appraisal System of the Former Civil Servant Appraisal System under Law Number 87/89/M "Estatuto dos Trabalhadores da Administração Pública de Macau"}

In accordance with the provisions of section 161 to 173 from Law Number 87/89/M "Estatuto dos Trabalhadores da Administração Pública de Macau, the performance of Macau civil servants was evaluated through the annual performance appraisal. The marking system of the old performance appraisal was divided into four rating level in descending order: excellent, satisfactory, fair and poor. The former focuses on the job performance for the previous year from January 1 to December 31.

In addition to the normal appraisal system, a special appraisal system also existed for appointed staff before their probation. The assessment result will have certain impact on the promotion. For instance, if a civil servant (during probation period) receives the result of fair-level, this will lead to the consequences of the contract is not renewed. In addition, the assessor of the civil servant usually is the superior who contacted most to that civil servant.

Furthermore, if there is any objection against the assessment result, that civil servant can initiate a suit to the higher administrative authorities of that subordinate agency, and the decision of the higher authorities will be the final result of that civil servant.

\section{The Shortcomings of the Former Civil Servant Appraisal System under Law Number 87/89/M "Estatuto dos Trabalhadores da Administração Pública de Macau”}

The above chapters had indicated some special disadvantages of the former civil servant appraisal system, thus, the system has lost its function to distinguish personnel quality and job performance of civil servants. The following chart shows the assessment results of various government agencies in 1999 (Lou, 2000):

Table 3. The assessment results of various government departments in 1999

\begin{tabular}{|l|l|l|l|l|}
\hline Excellent & Satisfactory & Fair & Poor & Sum \\
\hline $5746(62 \%)$ & $3496(38 \%)$ & $27(0 \%)$ & $0(0 \%)$ & 9269 \\
\hline
\end{tabular}

From the statistics, it was quite obvious that such performance appraisal system leads to the phenomenon of either excellent-level or satisfactory-level. Such results also echoed the factors affecting the performance appraisal from individuals and organizational perspectives from the literature of $\mathrm{Gu}$ (2006). As some evaluators may conduct bias toward particular individuals or groups, the appraisal report during 1999 strongly indicated the disadvantage mentioned by $\mathrm{Gu}$ (2006).

Moreover, it leads rapid promotion within the government in the long-term. Assuming that there is $70 \%$ of staff has reached the peak of their career within his nine years of working in government departments, and there will have no further possibility of promotion. Afterwards, a less motivated working environment could exist (Lou, 2000). 


\section{Conclusion}

To conclude, this phenomenon happened because of the following shortcomings existed in the former Civil Servant Appraisal System under Law Number 87/89/M "Estatuto dos Trabalhadores da Administração Pública de Macau” itself:

Firstly, the goal of assessment is not clearly defined lead to deviation from the spirit of assessment. Since the former appraisal system had not provided clear explanation to the purpose and the use of the appraisal, this made the former system cannot achieve the purpose of incentives and continuous improvement.

Secondly, the former appraisal system was lack of participation, communication and appeal mechanisms for the civil servants who was assessed. This might lead to higher authorities having too much power. Also, as lack of communication between upper and lower levels might also occur elements about lack of transparency and fair, this could result in unfairness of reward and punishment. Besides, as the former system lacked clear guidelines and objective criteria that led to the assessment methods were inconsistent, also contributed to the judgmental errors of personal bias since lack of objectivity. Based on the context mentioned above, this former performance appraisal system could not reflect the performance of civil servants. Thus, it could provide valuable feedback. In other words, the former appraisal system failed to achieve the principle of fairness, openness, objectivity, clear rewards and punishments. As a result, a new performance appraisal system appeared namely the Macau Civil Servant Performance Assessment System has been entered into force since 2005 until now.

\section{References}

Chou, B. K. P. (2004). Public sector reform in Macau after the handover. China Perspectives, $52,1-12$.

Face the reform of civil servant appraisal system (2000, September, 22). Macau Daily.

Gu, Y. W. (2006). Achievement evaluation. Beijing: Publishing House of Electronics Industry.

Heady, F. (2001). Public administration: A comparative perspective $\left(6^{\text {th }} \mathrm{ed}\right)$. New York: Marcel Dekker Inc.

Lam, S. K. (2005). Fully exercised the performance appraisal system: Excel the organizational spirit of civil servant. Administration, 18(1), 115-120.

Lou, M. (2000). Report of Macau Special Administrative Region government department performance appraisal. Administration, 13(4), 1105-1127.

Lu, G. L. (2004). Discussion of the performance appraisal system of civil servants in Macau. Macau Research, 24.

Macau Development Strategy Research Center (2003). Macau government framework and service quality. Macau: Macau Development Strategy Research Center

The civil servant team will select the excellent but ignore the poor (2000, November 14). 
Macau Daily.

Tompkins, J. (1995). Human resource management in government: Hitting the ground running. New York: Harper Collins College Publishers.

Yin, Y. F. (2008). The analysis of Macau civil servant appraisal system: From the perspective of governmental achievements. Journal of Lanzhou University (Social Sciences), 4, 495-498.

Waldo, D. (2006). The administrative state: A study of the political theory of American public administration. New Brunswick: Transaction Publishers.

Zhang, R.S. (2002). Administration (2 ${ }^{\text {nd }}$ ed.). Taipei: Sam Min Book.

\section{Copyright Disclaimer}

Copyright for this article is retained by the author(s), with first publication rights granted to the journal.

This is an open-access article distributed under the terms and conditions of the Creative Commons Attribution license (http://creativecommons.org/licenses/by/4.0/). 